\title{
INDOOR AIR QUALITY ASSESSMENT IN A SINGLE-FAMILY HOUSE EQUIPPED WITH DEMAND CONTROLLED MECHANICAL VENTILATION
}

\begin{abstract}
The paper presents the results of modelling airflow for ventilation of a single-family house with an area of $180 \mathrm{~m}^{2}$. The building was equipped with mechanical ventilation with the possibility of varying the airflow. The airflow was calculated as a function of carbon dioxide concentration. The presence of people in selected rooms was an internal source of carbon dioxide. In order to properly design of a ventilation system and then model the contamination level, ContamW software was used. The year-long cost analysis was carried out for the installation working with variable airflow (day, night). The analysis took into account the price of the electricity used by the fans of Air Handling Unit and meteorological data to estimate the power input to the heater of the Unit. Different scenarios of system operation were included as an input data in order to find a difference in energy consumption. The calculations were to answer the question of whether it is necessary to apply expensive and advanced system that enables individual control of the airflow in every room or use the simple control of the central unit to vary the airflow in the ventilation system of single-family houses. The difference in operating cost between the system that maintains 800 and 600 ppm reaches $100 \%$ and demonstrates the need of simple demand controlled ventilation system.
\end{abstract}

Keywords: airflow modelling, carbon dioxide concentration, energy demand, operating cost, variable airflow

\section{Introduction}

The proper indoor air quality is maintained by the airflow for ventilation, which, according to common design practice, is usually estimated on the basis of standards' minimum values exemplified in the national standard PN-83/B-03430 [1] or ASHRAE No. 62.1 [2]. Although the right approach should be based on the calculation of the airflow by estimating the pollutant emission. In a single-family house not only the hygienic minimum amount of the outside air per person, but water vapour gains as well as carbon dioxide $\left(\mathrm{CO}_{2}\right)$ emission should be taken into consideration. There is a way of simple calculations that help to simulate the pollution and estimate the optimum airflow.

Any ventilation system is dedicated to the provision of proper indoor air quality, according to individual needs and, obviously, according to standards. The required effect can be achieved by the replacement of used air with fresh air. Natural ventilation, without additional energy to move the air, or mechanical ventilation is the designer's/user's choice. The natural ventilation, even when supported, will not always provide the right airflow [3]. Along with the progress in building materials and structures, buildings strongly isolated

\footnotetext{
${ }^{1}$ Laboratory of Heating, Ventilation, Air Conditioning and Refrigeration, Cracow University of Technology, ul. Warszawska 24, 31-155 Kraków, Poland, phone +48 12628 2086, email: debowskimaciej92@ gmail.com

*Corresponding author: jmuller@pk.edu.pl
} 
from the external environment are increasingly more commonly built. The benefits of insulated and airtight buildings in the form of low energy demand require the use of mechanical ventilation with highly efficient heat recovery. A common opinion is that the use of mechanical ventilation is associated with many disadvantages, such as noise, high operating costs, and in general is expensive.

The best solution should be the mechanical ventilation as Wallner et al. [4] claim when analysing indoor environment quality in mechanically ventilated energy-efficient buildings. One of the options may be the demand controlled ventilation (DCV). The question is what control system should be used. A professional DCV system is too complicated for a single family house, so there is a simple method to achieve the goal of perfect indoor air quality.

The outside airflow in near zero energy buildings is based on standards that recommend the minimum values per person, but correctly it should be calculated from moisture and heat gains and/or gas pollutant emission. A man while breathing inhales oxygen and exhales carbon dioxide which can be harmful in higher concentrations. The emission rate increases with increasing activity therefore the airflow is not always constant but depends on situation/time of the day. An accurate estimation of pollution flow can more effective adjust the system to fulfilling the needs and to reduce operating cost at the same time.

This is illustrated by a Variable Air Volume (VAV) system controlled by adjusting the airflow individually for each room or an Air Handling Unit (AHU) with a variable speed fan that controls the airflow for the whole building. The intensity of ventilation can be controlled according to moisture gains, emission of pollutants or, directly, the presence of people. The main goal is to achieve the required air quality and optimization of running cost. When controlled by separate parameters - we have the example of DCV system.

In the literature many attempts to estimate the energy consumption of a ventilation system in dwellings are presented. Nielsen et al. [5] made measurements in a single-family house for periods of a couple of days in February, March and April using a demand controlled mechanical ventilation system. They conclude that controlling the air volume leads to energy savings up to 35\%. Evola et al. [6] calculated the energy input and cost of mechanical ventilation in comparison to natural ventilation. The air quality is calculated as a simple function of emission and the air flow for diluting the pollution. There is no modelling of the air quality and analysis is made for residential building in Italy. The authors estimate that simple payback time is estimated from 3 to 6 years. Laverge et al. [7] estimated energy demand in residential dwellings. Shin et al. [8] proved that $\mathrm{CO}_{2}$-based control system works the most effective in residential buildings. Woradechjumroen et al. [9] analysed the energy aspect in green buildings, as well as Widiastuti et al. [10].

Jiang et al. [11] selected $\mathrm{CO}_{2}$ concentrations as a very good indicator of occupancy and a means of indoor air quality estimator. Ioannou and Itard [12] in their research developed and applied in 30 residential dwellings in-situ method for real time measurements of the quantitative and qualitative parameters that affect thermal comfort. Many other authors choose $\mathrm{CO}_{2}$ as a primary indicator of indoor air quality [13]. In many cases the weather conditions do not affect the indoor $\mathrm{CO}_{2}$ concentrations [14]. Moreover the concentrations of $\mathrm{CO}_{2}$ is not uniform across the building and also may vary within the tested volume [15]. For the proper estimation of present concentrations of pollutions simple methods should be implemented such as gas microchromatography enables precise and accurate measurements of carbon dioxide concentrations [16]. Gladyszewska-Fiedoruk [17] discussed the necessity 
of supporting the natural ventilation with additional air stream, Lei et al. [18] discussed design strategies in residential buildings

However, the above publications do not show a simple control method and its impact on indoor air quality, nor the total annual cost of operating the ventilation system.

Carbon dioxide is a natural component of air and its concentration varies from 350 to $400 \mathrm{ppm}$ [19]. In the air exhaled by man the concentration of $\mathrm{CO}_{2}$ may vary from 35000 to $50000 \mathrm{ppm}$. When there is no proper ventilation that can remove or dilute $\mathrm{CO}_{2}$, it can accumulate causing sleepiness, loss of concentration (focusing), dyspnea and in high concentrations even coma or death [20]. According to the standards, in order to keep the designed category of a room designed for permanent, the $\mathrm{CO}_{2}$ level must be maintained at a certain level calculated as a surplus above the outdoors concentration (Table 1).

$\mathrm{CO}_{2}$ concentrations recommended by EN 15251 [21]

Table 1

\begin{tabular}{|c|c|}
\hline Category $^{*}$ & Corresponding $\mathrm{CO}_{2}[\mathrm{ppm}]$ above outdoors for energy calculations \\
\hline $\mathrm{I}$ & 350 \\
\hline II & 500 \\
\hline III & 800 \\
\hline IV & $>800$ \\
\hline
\end{tabular}

* Categories according to [21]: I - high level of expectation, II - normal level of expectation, III - an acceptable, moderate level of expectation, IV - values outside the criteria for the above categories

\section{Materials and methods}

The analysis is to answer to the question of whether there is a simple method of controlling the indoor air quality by changing the airflow and what is the difference in annual cost when the user wants to have a better indoor air quality.

The analysed building is a well-insulated, three-story structure of the area of $180 \mathrm{~m}^{2}$. Figure 1 presents the layout and the cross-section. The house is dedicated to a four-person family. The Air Handling Unit (AHU) is equipped with two fans, filters and a counter-flow heat recovery device. The air intake is on the east-side wall of the building, the air extract is placed on the roof. The air ducts are placed in the attic.

The AHU operation is controlled by the timer that changes the fan speed. On the supply and exhaust air ducts there are Constant Air Volume (CAV) controllers fixed, except the air supply to the living room and air exhaust from the kitchen, which enables keeping the constant flow in the occupied zones when the AHU operates at a reduced capacity.

The system is equipped with a hot water driven air heater that adds the required amount of heat to the air (up to $20^{\circ} \mathrm{C}$ ) when heat recovery is insufficient. The air prepared in AHU is distributed in the building by air ducts placed in the attic. The air is supplied into the clean zones (bedroom, living room etc.) by ceiling diffusers and discharged from dirty zones (kitchen, bathroom etc.)

The air flow was simulated by the ContamW model (version 3.2) that includes a supply exhaust fan and forced-air system operation, duct leakage and weather effects as well as factors related to contaminant dispersal including adsorption/desorption of water vapour and volatile organic compounds, surface losses of particles and nitrogen dioxide, outdoor contaminant concentrations, and occupant activities. Not all the data collected are presented in the paper, the authors focused on carbon dioxide only, as it is considered to be 
one of the most important components of indoor air quality assessment. ContamW enables the assessment of possible contaminant induced hazard for the inhabitants. The software package is the multi-zone airflow simulation package ContamW. The validation of multi-zone ventilation models against e.g. tracer gas measurements is well documented in literature [22-27].

a)

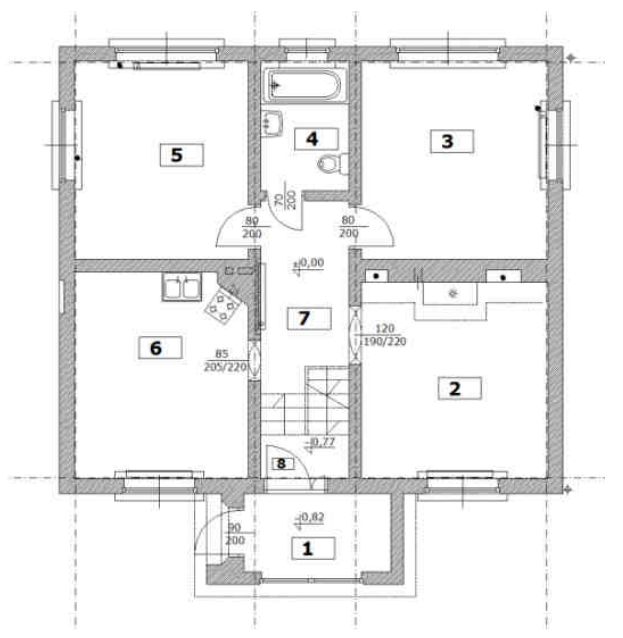

b)

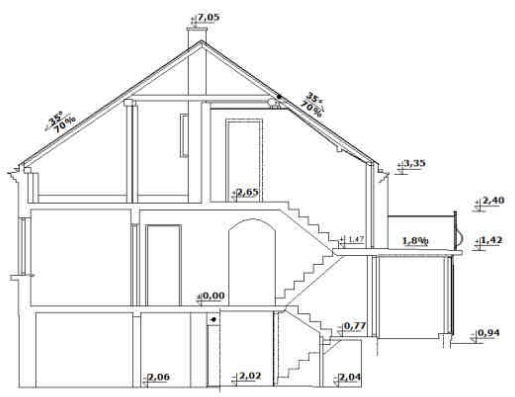

Fig. 1. a) Ground floor layout, b) Building cross-section

The abovementioned software was used for simulation the energy demand and indoor air quality by Bossche et al. [28] for simulation of exhaust-only ventilation system. Laverge et al. [7] simulated exhaust only mechanical ventilation system with local control.

Verijkazemi et al. [23] simulated indoor environment. Seong [29] simulated with ContamW a whole-house balanced mechanical ventilation system. Barbosa, Brum [24] used mentioned software for simulation of airborne contaminants. Heibati [25] used combined model for simulation of indoor environment.

The airflows were initially estimated according to minimum requirements given in national PN-83/B-03430 [1] standard. The $\mathrm{CO}_{2}$ concentration was kept below $800 \mathrm{ppm}$, as recommended by ASHRAE 62.1 [2].

Outside dry air composition acc. to ASHRAE Fundamentals 2009 [30]

\begin{tabular}{|c|c|c|c|}
\hline Gas & Symbol & Mole mass [kg/kmol] & Concentration by volume \\
\hline Nitrogen & $\mathrm{N}_{2}$ & 28 & 78.084 \\
\hline Oxygen & $\mathrm{O}_{2}$ & 32 & 20.948 \\
\hline Argon & $\mathrm{Ar}$ & 40 & 0.934 \\
\hline Carbon dioxide & $\mathrm{CO}_{2}$ & 44 & 0.038 \\
\hline Water vapor & $\mathrm{H}_{2} \mathrm{O}$ & 18 & 0.000 \\
\hline
\end{tabular}

The first step was to estimate the supply air parameters: temperature $t_{\text {sup }}=20{ }^{\circ} \mathrm{C}$, relative humidity $\varphi_{\text {sup }}=50 \%$ (assumed as constant) and air composition shown in Table 2 . 
The model maps the actual layout of the rooms (Fig. 2) including the shape, area and volume. The building was modelled taking into account the windows and doors location and their leakage rate.

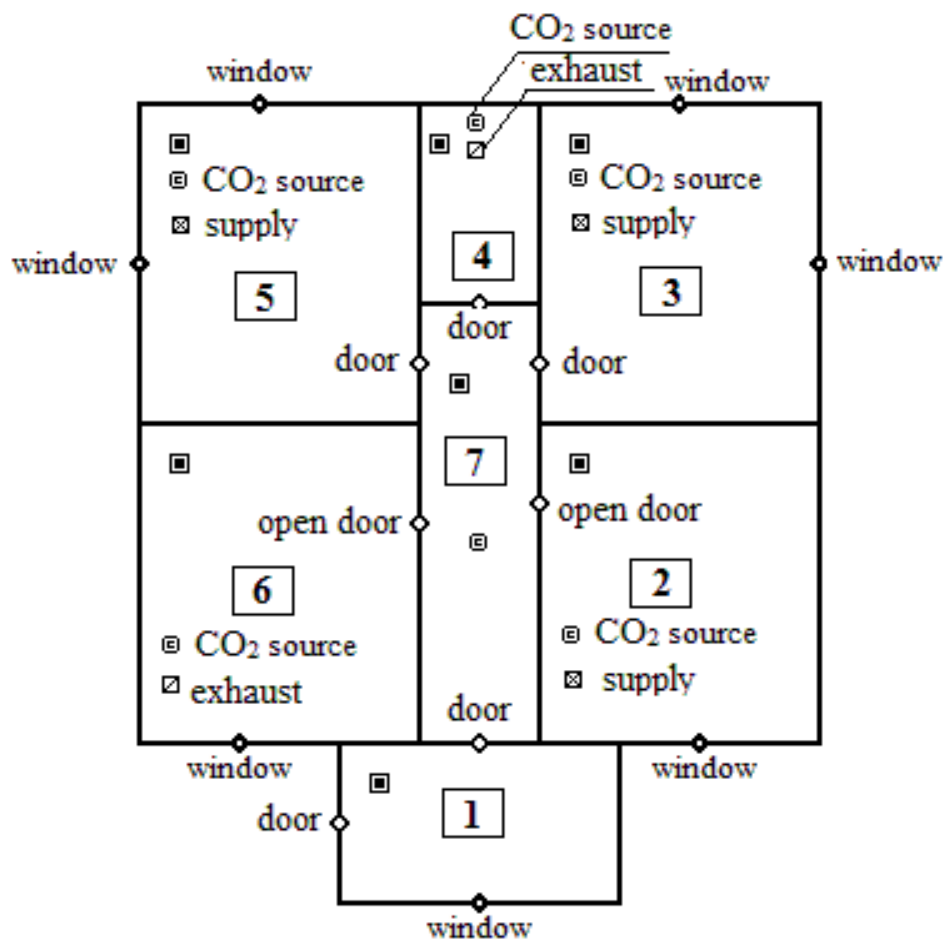

Fig. 2. Ground floor layout - simulation input data. 1 - entrance, 2 - living room, 3 - bedroom, 4 - bathroom, 5 - children's room, 6 - kitchen, 7 - hall

The main air exhaust grilles were placed in the kitchen and bathroom. These are the rooms where the water vapour, $\mathrm{CO}_{2}$ and other pollutants gains are the highest. The air supply terminals were placed in the living room, bedroom and the children's room. The air flow between the rooms was allowed by the openings in doors and a transfer grille in the bathroom door. The air flow between the kitchen, living room and the hall was allowed through the whole area of the open door.

The simulation was performed for four inhabitants, taking into consideration their variable activity and presence in different rooms. The daily schedule of $\mathrm{CO}_{2}$ emission was simulated for each inhabitant taking into account their time of sleep, meal, bath, rest and work. The daily schedule was set based on interviews with the inhabitants. Those activities were described by the emission of carbon dioxide as follows [31, 32]:

- $\quad$ Sleeping - $10 \mathrm{dm}^{3}$ of $\mathrm{CO}_{2} / \mathrm{h}$

- Sitting person $-15 \mathrm{dm}^{3}$ of $\mathrm{CO}_{2} / \mathrm{h}$

- Light work - $20 \mathrm{dm}^{3}$ of $\mathrm{CO}_{2} / \mathrm{h}$

- Medium work - $35 \mathrm{dm}^{3}$ of $\mathrm{CO}_{2} / \mathrm{h}$

Daily schedule of $\mathrm{CO}_{2}$ emission is presented in graphs - Figure 3. 
a)

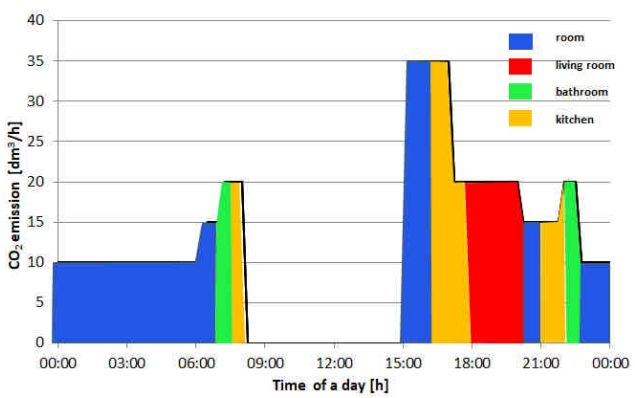

c)

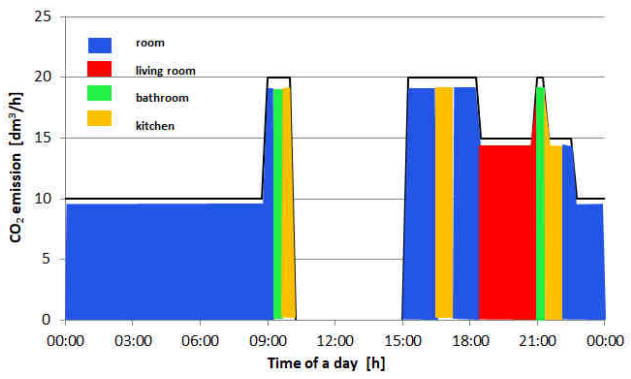

b)

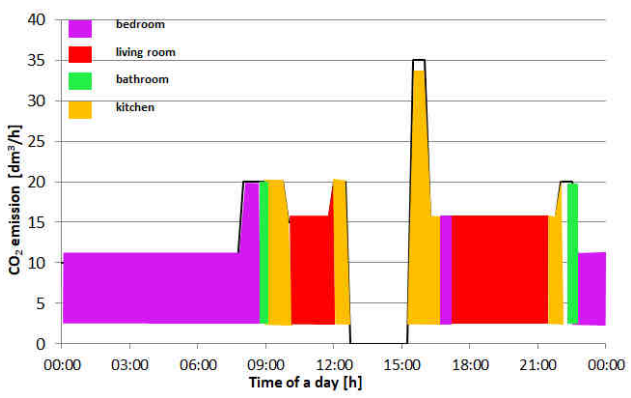

d)

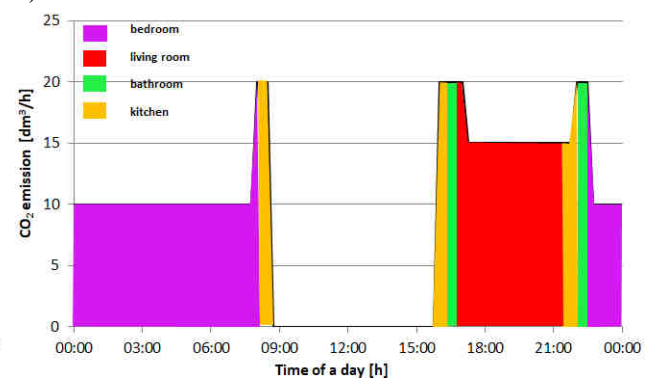

Fig. 3. Hourly schedule of inhabitants ( $\mathrm{CO}_{2}$ emission): a) daily schedule for person 1 , b) daily schedule for person 2,c) daily schedule for person 3, d) daily schedule for person 4

Table 3

Ventilation airflows for scenario 1

\begin{tabular}{|c|c|c|c|c|}
\hline \multirow{2}{*}{ Room } & \multicolumn{2}{|c|}{ Supply airflow $\left[\mathbf{m}^{3} / \mathbf{h}\right]$} & \multicolumn{2}{c|}{ Exhaust airflow $\left[\mathbf{m}^{3} / \mathbf{h}\right]$} \\
\cline { 2 - 5 } & $7: 00-23: 00$ & $23: 00-7: 00$ & $7: 00-23: 00$ & $23: 00-7: 00$ \\
\hline Kitchen $\left[14.53 \mathrm{~m}^{2}\right]$ & - & - & 280 & 120 \\
\hline Hall $\left[9.63 \mathrm{~m}^{2}\right]$ & - & - & - & - \\
\hline Room $1\left[14.26 \mathrm{~m}^{2}\right]$ & 100 & 100 & - & - \\
\hline Bedroom $\left[15.25 \mathrm{~m}^{2}\right]$ & 60 & 60 & - & - \\
\hline Living room $\left[14.73 \mathrm{~m}^{2}\right]$ & 200 & 40 & - & 50 \\
\hline Bathroom $\left[4.67 \mathrm{~m}^{2}\right]$ & - & - & 30 & 30 \\
\hline Cellar $\left[8.07 \mathrm{~m}^{2}\right]$ & - & - & 360 & 200 \\
\hline Total & 360 & 200 & & \\
\hline
\end{tabular}

Based on the performed simulations and pollutants concentrations the airflows were adjusted to achieve the recommended indoor air quality. In the nighttime the airflow was reduced in the AHU but constant air volume controllers did not reduce the airflow in the bedroom and living room where people could be present. The kitchen exhaust was also kept constant. The energy reduction was obtained with no air quality loss.

Calculated airflows are presented in Table 3.

To avoid expensive and advanced control system, the AHU operated in two modes: night and day mode with the airflow calculated from the simulation. In this way a simple Demand Controlled Ventilation (DCV) system was created. Night mode is active for 8 hours from 23:00 (11 p.m.) to 7:00 when supply and exhaust airflows are $200 \mathrm{~m}^{3} / \mathrm{h}$ (scenario 1). Day mode is active for 16 hours from 7:00 to 23:00 (11 p.m.) when supply and 
exhaust airflows are $360 \mathrm{~m}^{3} / \mathrm{h}$, (scenario 1). Reduced airflow in night mode allows keeping $\mathrm{CO}_{2}$ below the recommended level $(800 \mathrm{ppm})$ for standard design (scenario 1). Figure 4 presents the results.

The results obtained for the first scenario was the starting point for further design process like AHU selection, air ducts dimensioning, etc.

\section{Analysed scenarios}

Using the ContamW software five different scenarios and different maximum concentrations were analysed. The goal was to estimate the airflows and to find the setpoint for the DCV system. Moreover the simulations made possible to compare the total cost of running the system.

The scenarios are as follows:

- Scenario 1 - "standard design" - for given input data the maximum concentration of $\mathrm{CO}_{2}$ was set to $800 \mathrm{ppm}$.

- Scenario 2 - "the maximum concentration" of $\mathrm{CO}_{2}$ was set to $700 \mathrm{ppm}$.

- Scenario 3 - "better quality" - the maximum concentration of $\mathrm{CO}_{2}$ was set to $600 \mathrm{ppm}$.

- Scenario 4 - "the minimum cost" - the maximum concentration of $\mathrm{CO}_{2}$ was set to $1000 \mathrm{ppm}$.

- Scenario 5 - "party time" - for given input data 3 persons were added between 17:00-21:00 (5 p.m. to 9 p.m.). They are supposed to stay in the living room and their activity will produce $20 \mathrm{dm}^{3}$ of $\mathrm{CO}_{2}$ per hour and the maximum concentration of $\mathrm{CO}_{2}$ was set to $800 \mathrm{ppm}$.

\section{Calculation of the airflows required to keep the required $\mathrm{CO}_{2}$ concentration level - DCV setpoint}

Scenario 1 - the airflows calculated are presented in Table 4 and the concentrations values are presented in Figure 4.

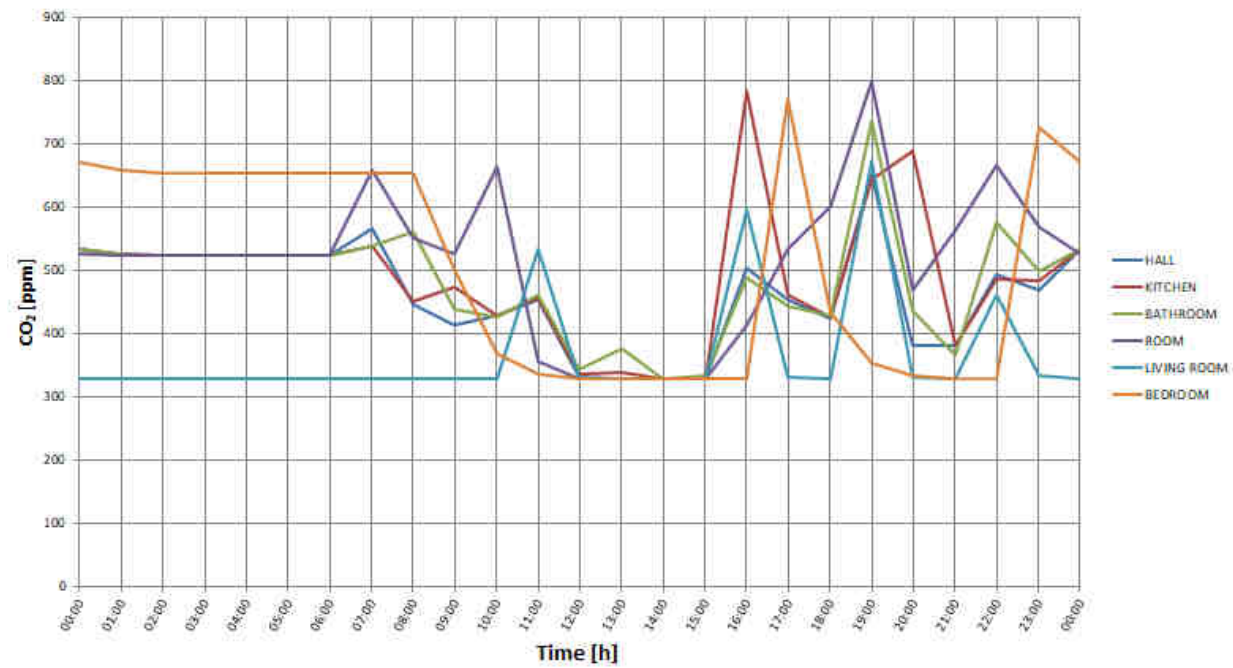

Fig. 4. $\mathrm{CO}_{2}$ concentration (Scenario 1) in different rooms 
Ventilation airflows for scenarios 2-5

\begin{tabular}{|c|c|c|c|c|}
\hline \multirow{2}{*}{ Room } & \multicolumn{2}{|c|}{ Supply airflow $\left[\mathrm{m}^{3} / \mathrm{h}\right]$} & \multicolumn{2}{|c|}{ Exhaust airflow $\left[\mathrm{m}^{3} / \mathrm{h}\right]$} \\
\hline & 7:00-23:00 & 23:00-7:00 & 7:00-23:00 & 23:00-7:00 \\
\hline Scenario 1 & \multicolumn{4}{|c|}{ Standard design } \\
\hline Kitchen $\left[14.53 \mathrm{~m}^{2}\right]$ & - & - & 340 & 130 \\
\hline Hall $\left[9.63 \mathrm{~m}^{2}\right]$ & - & - & - & - \\
\hline Room $1\left[14.26 \mathrm{~m}^{2}\right]$ & 140 & 140 & - & - \\
\hline Bedroom $\left[15.25 \mathrm{~m}^{2}\right]$ & 100 & 100 & - & - \\
\hline Living room $\left[14.73 \mathrm{~m}^{2}\right]$ & 250 & 40 & - & - \\
\hline Bathroom $\left[4.67 \mathrm{~m}^{2}\right]$ & - & - & 120 & 120 \\
\hline Cellar $\left[8.07 \mathrm{~m}^{2}\right]$ & - & - & 30 & 30 \\
\hline \multirow[b]{2}{*}{ Scenario 2} & 490 & 280 & 490 & 280 \\
\hline & \multicolumn{4}{|c|}{ Max. $\mathrm{CO}_{2}=700 \mathrm{ppm}$} \\
\hline Kitchen $\left[14.53 \mathrm{~m}^{2}\right]$ & - & - & 340 & 130 \\
\hline Hall $\left[9.63 \mathrm{~m}^{2}\right]$ & - & - & - & - \\
\hline Room $1\left[14.26 \mathrm{~m}^{2}\right]$ & 140 & 140 & - & - \\
\hline Bedroom $\left[15.25 \mathrm{~m}^{2}\right]$ & 100 & 100 & - & - \\
\hline Living room $\left[14.73 \mathrm{~m}^{2}\right]$ & 250 & 40 & - & - \\
\hline Bathroom $\left[4.67 \mathrm{~m}^{2}\right]$ & - & - & 120 & 120 \\
\hline Cellar $\left[8.07 \mathrm{~m}^{2}\right]$ & - & - & 30 & 30 \\
\hline \multirow[b]{2}{*}{ Scenario 3} & 490 & 280 & 490 & 280 \\
\hline & \multicolumn{4}{|c|}{ Better quality, max. $\mathrm{CO}_{2}=600 \mathrm{ppm}$} \\
\hline Kitchen $\left[14.53 \mathrm{~m}^{2}\right]$ & - & - & 460 & 220 \\
\hline Hall $\left[9.63 \mathrm{~m}^{2}\right]$ & - & - & - & - \\
\hline Room $1\left[14.26 \mathrm{~m}^{2}\right]$ & 210 & 210 & - & - \\
\hline Bedroom $\left[15.25 \mathrm{~m}^{2}\right]$ & 150 & 150 & - & - \\
\hline Living room $\left[14.73 \mathrm{~m}^{2}\right]$ & 280 & 40 & - & - \\
\hline Bathroom $\left[4.67 \mathrm{~m}^{2}\right]$ & - & - & 150 & 150 \\
\hline Cellar $\left[8.07 \mathrm{~m}^{2}\right]$ & - & - & 30 & 30 \\
\hline \multirow[b]{2}{*}{ Scenario 4} & 640 & 400 & 640 & 400 \\
\hline & \multicolumn{4}{|c|}{ Minimum cost } \\
\hline Kitchen $\left[14.53 \mathrm{~m}^{2}\right]$ & - & - & 150 & 70 \\
\hline Hall $\left[9.63 \mathrm{~m}^{2}\right]$ & - & - & - & - \\
\hline Room $1\left[14.26 \mathrm{~m}^{2}\right]$ & 80 & 80 & - & - \\
\hline Bedroom $\left[15.25 \mathrm{~m}^{2}\right]$ & 50 & 50 & - & - \\
\hline Living room $\left[14.73 \mathrm{~m}^{2}\right]$ & 100 & 20 & - & - \\
\hline Bathroom $\left[4.67 \mathrm{~m}^{2}\right]$ & - & - & 50 & 50 \\
\hline Cellar $\left[8.07 \mathrm{~m}^{2}\right]$ & - & - & 30 & 30 \\
\hline \multirow[b]{2}{*}{ Scenario 5} & 230 & 150 & 230 & 150 \\
\hline & \multicolumn{4}{|c|}{ Party time } \\
\hline Kitchen $\left[14.53 \mathrm{~m}^{2}\right]$ & - & - & 440 & 180 \\
\hline Hall $\left[9.63 \mathrm{~m}^{2}\right]$ & - & - & - & - \\
\hline Room $1\left[14.26 \mathrm{~m}^{2}\right]$ & 140 & 140 & - & - \\
\hline Bedroom $\left[15.25 \mathrm{~m}^{2}\right]$ & 100 & 100 & - & - \\
\hline Living room $\left[14.73 \mathrm{~m}^{2}\right]$ & 300 & 40 & - & - \\
\hline Bathroom $\left[4.67 \mathrm{~m}^{2}\right]$ & - & - & 70 & 70 \\
\hline Cellar $\left[8.07 \mathrm{~m}^{2}\right]$ & - & - & 30 & 30 \\
\hline Total & 540 & 280 & 540 & 280 \\
\hline
\end{tabular}




\section{Calculations of electrical energy cost}

Using the number of hours in one year, number of day/night hours, the annual power consumption of the fan was calculated from the value of Specific Fan Power (in $\left.\mathrm{kWh} /\left(\mathrm{m}^{3} / \mathrm{s}\right)\right)$ given by the manufacturer. Then using the energy price the annual cost of two fans running was calculated.

\section{Calculations of thermal energy cost}

The outside air must be heated up to the supply temperature $\left(+20{ }^{\circ} \mathrm{C}\right)$. The heat recovery reduces the heat energy demand. Heat recovery efficiency depends on the airflow in the AHU. The function (1) was derived from producer's data:

$$
\eta=-0.0188 \mathrm{~V}+95.75
$$

The air heater turns off when the heat recovery outlet temperature, $t_{\mathrm{r}}$ reaches $20{ }^{\circ} \mathrm{C}$.

Heat recovery outlet temperature, $t_{r}$ was calculated from:

$$
t_{r}=t_{z}+\eta \cdot\left(t_{p}-t_{z}\right) \quad\left[{ }^{\circ} \mathrm{C}\right]
$$

where: $t_{z}$ - outside temperature $\left[{ }^{\circ} \mathrm{C}\right], \eta$ - heat recovery efficiency $[-], t_{p}$ - room temperature $\left[{ }^{\circ} \mathrm{C}\right]$.

The heater capacity was calculated from:

$$
Q_{N}=V \cdot \rho \cdot c_{p} \cdot\left(t_{\text {set }}-t_{r}\right) \quad[\mathrm{kW}]
$$

where: $V$ - airflow $\left[\mathrm{m}^{3} / \mathrm{h}\right], \quad \rho$ - air density $\left[\mathrm{kg} / \mathrm{m}^{3}\right], c_{p}$ - air specific heat $[\mathrm{kJ} /(\mathrm{kg} \cdot \mathrm{K})]$, $t_{\text {set }}$ - temperature of supply air $\left[{ }^{\circ} \mathrm{C}\right]$.

The total heater energy:

$$
E_{h}=\sum_{i=1}^{n} Q_{n i}=V_{i} \cdot \rho \cdot c_{p} \cdot\left(t_{s e t}-t_{r, i}\right)[\mathrm{kW}]
$$

where: $n=$ number of hours in analysed period, $i=$ the hour.

\section{Results and discussion}

The analysed scenarios were selected to simulate various situations at home.

Scenario 2 - the maximum concentration of $\mathrm{CO}_{2}$ was set to $700 \mathrm{ppm}$. The airflows calculated are presented in Table 4 and the concentrations values are presented in Figure 5.

Scenario 3 - the maximum concentration of $\mathrm{CO}_{2}$ was set to $600 \mathrm{ppm}$. The airflows calculated are presented in Table 4 and the concentrations values are presented in Figure 5.

Scenario 4 - the maximum concentration of $\mathrm{CO}_{2}$ was set to $1000 \mathrm{ppm}$. The airflows calculated are presented in Table 4 and the concentrations values are presented in Figure 6.

Scenario 5 - for given input data 3 persons were added between 17:00-21:00 (5 p.m. to 9 p.m.). They were supposed to stay in the living room and their activity would produce $20 \mathrm{dm}^{3}$ of $\mathrm{CO}_{2}$ per hour and the maximum concentration of $\mathrm{CO}_{2}$ was set to $800 \mathrm{ppm}$. The airflows calculated are presented in Table 4 and the concentrations values are presented in Figure 6. 
a)

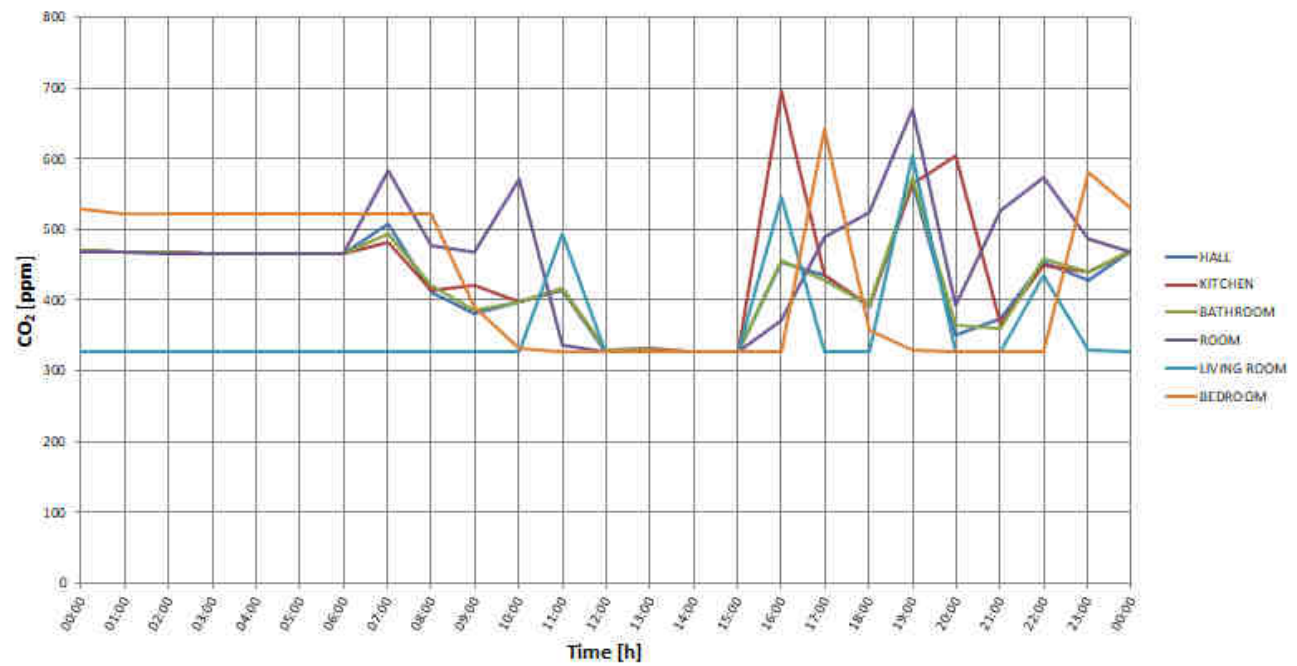

b)

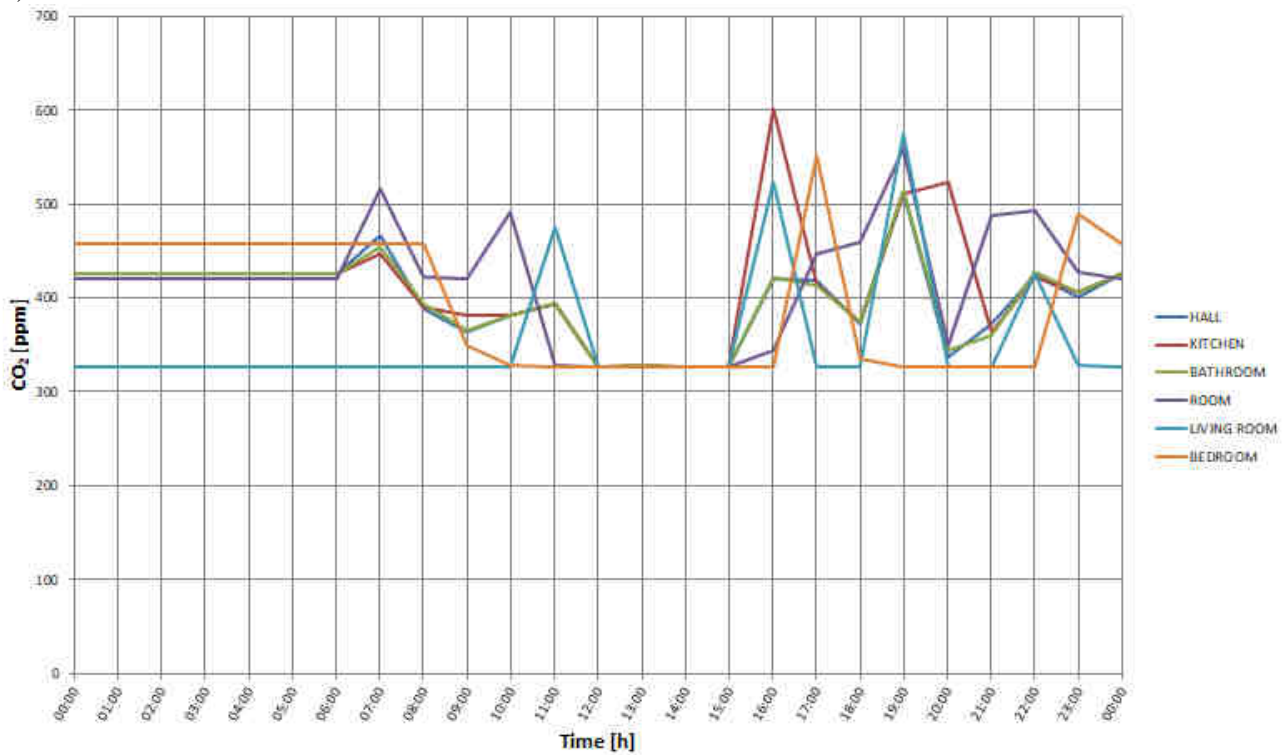

Fig. 5. $\mathrm{CO}_{2}$ concentration in different rooms. Scenario: a) 2 and b) 3

Figures 4-6 show that it is possible to maintain the required $\mathrm{CO}_{2}$ level using simple strategy of control the ventilation system. The maximum level is not exceeded. The residents need to be aware of the difference in the cost of maintaining the chosen $\mathrm{CO}_{2}$ level as shown in the next chapter. 
a)

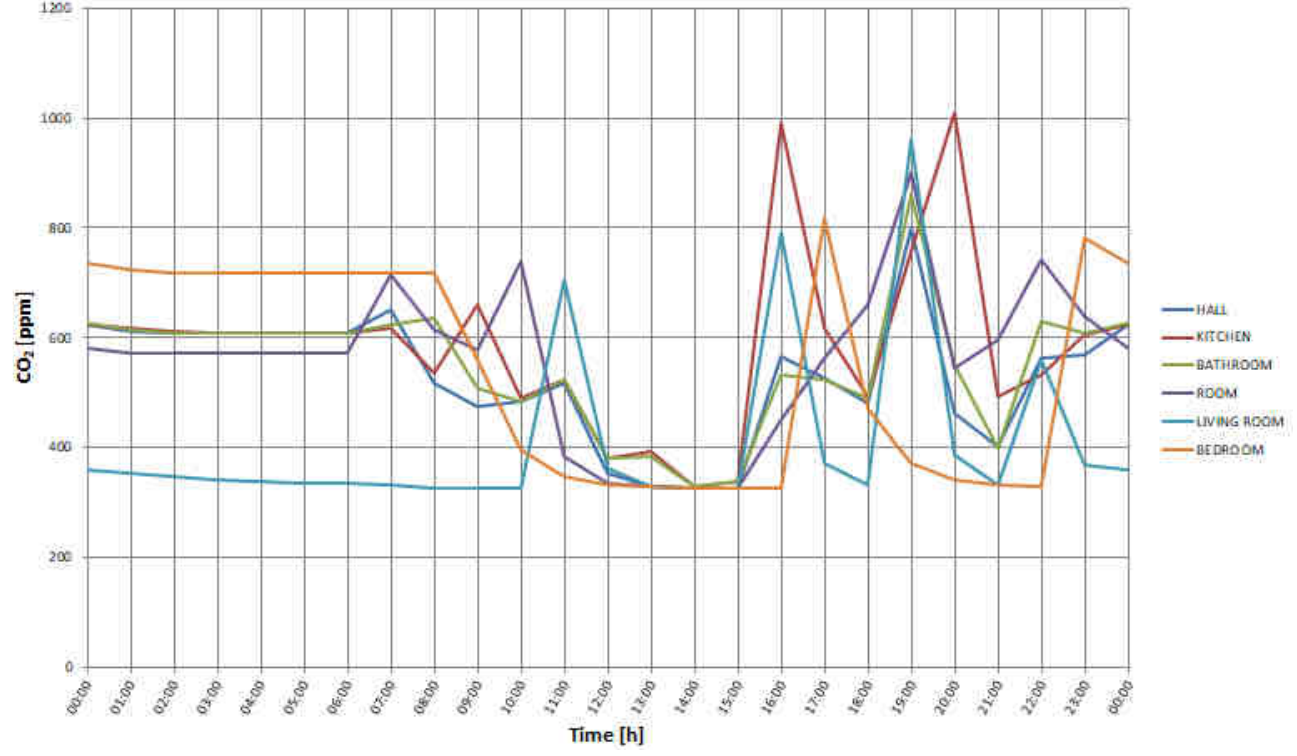

b)

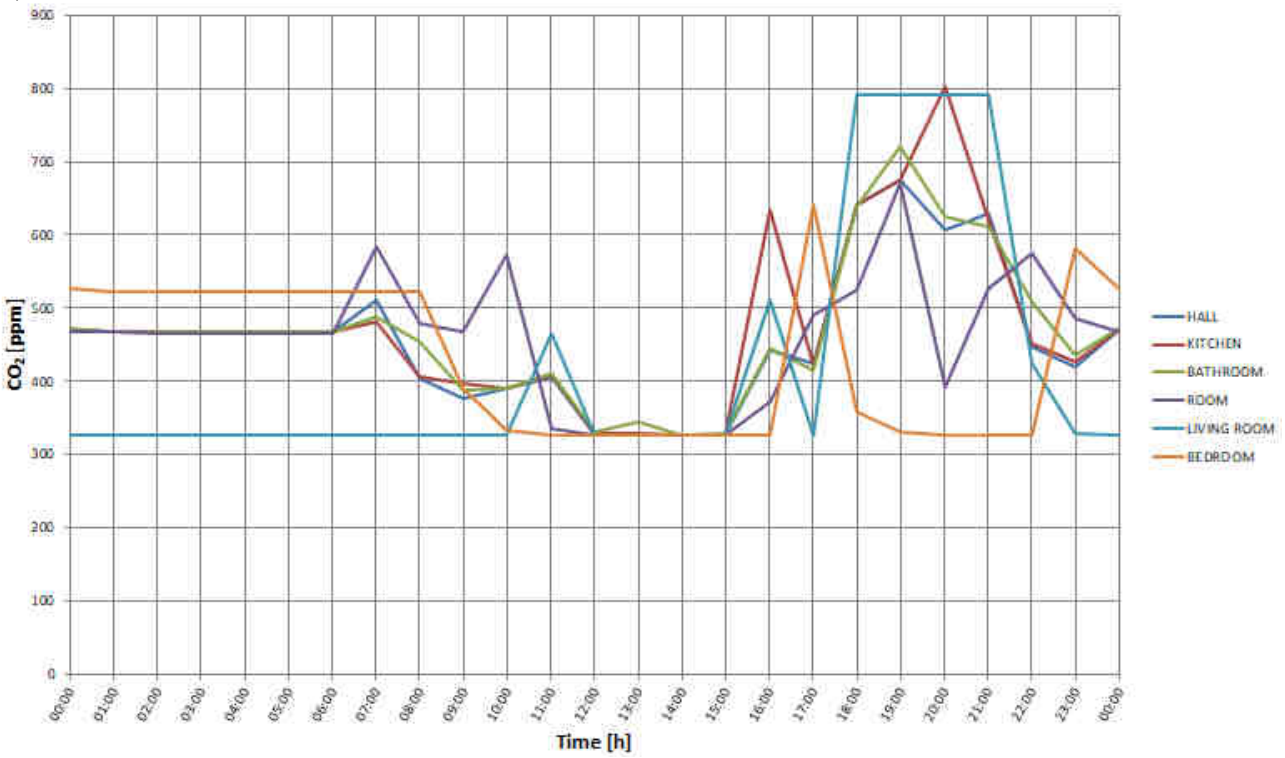

Fig. 6. $\mathrm{CO}_{2}$ concentration in different rooms Scenario: a) 4 and b) 5

\section{Calculations of electrical energy cost}

Examples of calculations are shown for scenario 1. First the number of hours was calculated, for the sake of cost estimation the total number of hours and the number of day and night hours was calculated: Number of hours in one year: $8760 \mathrm{~h}$ 
Number of hours of maximum airflow (daytime): 16 hours $\cdot 365$ days $=5840$ hours

Number of hours of minimum airflow (night): 8 hours 365 days $=2920$ hours

Power consumption of the fan was based on the value of Specific Fan Power (SFP) given in technical data sheet of AHU.

Specific fan power: $\quad \mathrm{SFP}=0.75 \mathrm{~kW} /\left(\mathrm{m}^{3} \cdot \mathrm{s}\right)$

Power input for the fan (at $V_{\max }=360 \mathrm{~m}^{3} / \mathrm{h}$ ) $P_{f \max }=75 \mathrm{~W}$

Power input for the fan (at $V_{\text {min }}=200 \mathrm{~m}^{3} / \mathrm{h}$ ) $P_{f \min }=42 \mathrm{~W}$

The above data allowed for calculation of total energy consumed per year.

Energy consumed for $V_{\max } \quad E_{V \max }=438 \mathrm{kWh} /$ year

Energy consumed for $V_{\min } \quad E_{V \min }=122 \mathrm{kWh} /$ year

Total

$E_{\text {tot }}=560 \mathrm{kWh} /$ year

Energy price ${ }^{\mathrm{i}}: 0.14 € / \mathrm{kWh}$ ('tariff G11 - data from Poland 21.07.2020)

Annual cost of the energy of two fans running $C_{f a n}=156.8 €$

\section{Calculations of thermal energy cost}

Examples of calculations made for scenario 1 using meteorological data (reference year) are shown below. The air is preheated in heat recovery exchanger with the efficiency dependent of the flow, then the air must be heated up to $20{ }^{\circ} \mathrm{C}$ using natural gas water heater. Water was used as a heat transfer fluid.

Table 5

Heater capacity calculations for January 1 (example chart)

\begin{tabular}{|c|c|c|c|c|c|}
\hline Month & Day & Time & $\begin{array}{c}\text { Outside } \\
\text { temperature }\end{array}$ & $\begin{array}{c}\text { Heat recovery outlet } \\
\text { temperature }\end{array}$ & Heater capacity \\
\hline & & & {$\left[{ }^{\circ} \mathbf{C}\right]$} & {$\left[{ }^{\circ} \mathbf{C}\right]$} & {$[\mathbf{k W}]$} \\
\hline \multirow{24}{*}{1} & \multirow{24}{*}{1} & 0 & 2.1 & 18.6 & 0.10 \\
\hline & & 1 & 1.7 & 18.5 & 0.10 \\
\hline & & 2 & 1.2 & 18.5 & 0.10 \\
\hline & & 3 & 0.8 & 18.5 & 0.10 \\
\hline & & 4 & 2 & 18.6 & 0.10 \\
\hline & & 5 & 3.1 & 18.6 & 0.09 \\
\hline & & 6 & 4.3 & 18.7 & 0.08 \\
\hline & & 7 & 4.5 & 18.8 & 0.08 \\
\hline & & 8 & 4.8 & 18.3 & 0.20 \\
\hline & & 9 & 5 & 18.4 & 0.20 \\
\hline & & 10 & 5.1 & 18.4 & 0.20 \\
\hline & & 11 & 5.1 & 18.4 & 0.20 \\
\hline & & 12 & 5.2 & 18.4 & 0.20 \\
\hline & & 13 & 4.7 & 18.3 & 0.20 \\
\hline & & 14 & 4.3 & 18.3 & 0.21 \\
\hline & & 15 & 3.8 & 18.2 & 0.21 \\
\hline & & 16 & 2.7 & 18.1 & 0.23 \\
\hline & & 17 & 1.5 & 18.0 & 0.25 \\
\hline & & 18 & 0.4 & 17.8 & 0.26 \\
\hline & & 19 & -0.1 & 17.8 & 0.27 \\
\hline & & 20 & -0.7 & 17.7 & 0.27 \\
\hline & & 21 & -1.2 & 17.7 & 0.28 \\
\hline & & 22 & -1.6 & 17.6 & 0.29 \\
\hline & & 23 & -2.1 & 18.2 & 0.21 \\
\hline
\end{tabular}


Assumptions:

The efficiency of heat recovery is a linear function of the airflow and has been calculated based on manufacturer's data. The limit values were as follows:

- Heat recovery efficiency (for $V_{\max }=360 \mathrm{~m}^{3} / \mathrm{h}$ ) $=89 \%$

- Heat recovery efficiency (for $V_{\min }=200 \mathrm{~m}^{3} / \mathrm{h}$ ) $=92 \%$

The air heater was turned off when the heat recovery outlet temperature, $t_{r}$ reached $20{ }^{\circ} \mathrm{C}$. The air was heated using water as heat transfer fluid. The water was heated up in a gas water heater of efficiency $\eta=90 \%$. The calculations were made for every hour of reference year data. For the given day, for every hour, first the temperature of the air leaving the heat recovery heat exchanger was calculated, then the complementary energy was calculated. An example of calculations chart is presented in Table 5.

- The results were as follows: The total heater energy $E_{h}=1034.68 \mathrm{kWh} /$ year

- The price of natural gas ${ }^{\mathrm{i}} P_{g}=0.058 € / \mathrm{kWh}$, ( $^{\mathrm{i}}$ for tariff $\mathrm{W}-1$ data from Poland 16.06.2020)

- Annual cost of heating the air: $C_{h}=1034.68 \mathrm{kWh} /$ year $\cdot 0.058 € / \mathrm{kWh}=60.01 €$

\section{Comparison of analysed scenarios}

According to the procedure presented above, all the scenarios and all year-round calculations were performed. Table 6 presents the results.

Table 6

Comparison between scenarios

\begin{tabular}{|c|c|c|c|c|c|c|}
\cline { 3 - 7 } \multicolumn{2}{c|}{} & Scenario 1 & Scenario 2 & Scenario 3 & Scenario 4 & Scenario 5 \\
\hline Minimum airflow & {$\left[\mathrm{m}^{3} / \mathrm{h}\right]$} & 200 & 280 & 400 & 150 & 280 \\
\hline Maximum airflow & {$\left[\mathrm{m}^{3} / \mathrm{h}\right]$} & 360 & 490 & 640 & 230 & 540 \\
\hline AHU type and model & & $\begin{array}{c}\text { Domekt CF } \\
500 \mathrm{~F}\end{array}$ & $\begin{array}{c}\text { Domekt CF } \\
500 \mathrm{~F}\end{array}$ & $\begin{array}{c}\text { Domekt CF } \\
700 \mathrm{H}\end{array}$ & $\begin{array}{c}\text { Domekt CF } \\
400 \mathrm{~V}\end{array}$ & $\begin{array}{c}\text { Domekt CF } \\
500 \mathrm{~F}\end{array}$ \\
\hline $\begin{array}{c}\text { Heat recovery efficiency } \\
\text { for minimum airflow }\end{array}$ & & $92 \%$ & $90 \%$ & $89 \%$ & $84.5 \%$ & $90 \%$ \\
\hline $\begin{array}{c}\text { Heat recovery efficiency } \\
\text { for maximum airflow }\end{array}$ & & $89 \%$ & $86 \%$ & $84 \%$ & $83.5 \%$ & $85 \%$ \\
\hline Electrical energy used & {$[\mathrm{kWh} /$ year] } & 1120 & 1534 & 2044 & 742 & 1654 \\
\hline Heat energy used & {$[\mathrm{kWh} /$ year] } & 1034.68 & 1796.76 & 2716.08 & 1113.78 & 2043.41 \\
\hline Cost of electrical energy & {$[€]$} & 157 & 215 & 286 & 104 & 232 \\
\hline Cost of the natural gas & {$[€]$} & 60 & 104 & 158 & 65 & 119 \\
\hline Total cost & {$[€]$} & $\mathbf{2 1 7}$ & $\mathbf{3 1 9}$ & $\mathbf{4 4 4}$ & $\mathbf{1 6 9}$ & $\mathbf{3 5 1}$ \\
\hline $\begin{array}{c}\text { Difference from the } \\
\text { Scenario 1 }\end{array}$ & {$[€]$} & 0 & 102 & 227 & -48 & 134 \\
\hline $\begin{array}{c}\text { Difference from the } \\
\text { Scenario 1 }\end{array}$ & {$[\%]$} & 0 & 47.0 & 112.9 & -22.1 & 61.8 \\
\hline
\end{tabular}

Similarly as in Nielsen and Drivsholm [5] the strategy shows the ability of DCV system to keep the proper indoor air quality at an acceptable level. Supply-exhaust system with heat recovery performs at lower cost as compared to different locations in Europe [7].

The obtained results showed a real increase in the total cost when the owner wanted to keep a better air quality in the building. For the analysed system, which was originally supposed to keep the maximum concentration of $\mathrm{CO}_{2}$ below $800 \mathrm{ppm}$, the annual cost of operation was about $205 €$. To keep the concentration level down to $700 \mathrm{ppm}$ would cost extra $100 €$. The cost doubled (in comparison with scenario 1) when the pollution was to be 
kept below $600 \mathrm{ppm}$. To keep the concentration below the ASHRAE 62.1 [2] limit (1000 ppm) one would have to pay about $48 €$ less per year. Moreover in scenario 4 , due to reduced airflows, the AHU could be selected one size down (investment cost would be lower). The savings were $22.1 \%$ lower in comparison to scenario 1 . Scenario no 5 (party time) took into consideration additional emission from more sources and the system was to keep the concentration below $800 \mathrm{ppm}$. The system designed for that purpose was able to keep everyday (no extra people) concentration below 700 ppm and below 800 ppm with some guests in the house. The operation cost was $134 €$ annually higher than the one in scenario 1. As compared to Evola et al. [6] the cost of keeping the $600 \mathrm{ppm}$ of $\mathrm{CO}_{2}$ is about the same and supports the thesis of better indoor air quality kept by double - flow DCV mechanical ventilation. As in Zender-Swiercz [33] the right $\mathrm{CO}_{2}$ concentration is better kept by mechanical, DCV ventilation.

The results presented are based on the assumptions that affect the outcomes regarding the resident's behaviour, natural gas prices and electricity. In addition the initial cost of a mechanical ventilation system may vary depending on the quality and manufacturer. However, the unfavourable variability of these parameters only slightly modifies the outcomes, without significantly affecting the positive conclusions regarding the financial aspect of controlled mechanical ventilation systems. It is also true that occupants might not appreciate the fact of being obliged to keep windows shut, and to rely solely only on a mechanical ventilation system that they cannot individually control.

Internal load schedules should be thoroughly studied to adjust the scenarios to a large group of residents as in Ben-David and Waring [34].

\section{Conclusion}

The building ventilation system has an influence on our health and comfort. The operation cost reduction in modern building should not lead to degraded comfort. Near zero energy buildings being well insulated and airtight giving low energy losses have to be equipped with mechanical ventilation (with heat recovery) that should be controlled according to needs (DCV).

The goal of the study was to analyse an annual operation of a mechanical ventilation system designed according to everyday activity of inhabitants. The adjustment was made by means of controlling the airflow supplied and exhausted by Air Handling Unit by DCV approach. The system provided the desired low concentration of $\mathrm{CO}_{2}$ and enabled some cost reduction due to the use of efficient heat recovery. Five scenarios were analysed: the first three were based on assumed emission of $\mathrm{CO}_{2}$ and the difference was in the maximum level of $\mathrm{CO}_{2}$ kept by the ventilation system (800, 700 and 600 respectively). The annual cost of operation of the system varies from $217 €$ for scenario 1 (standard design) and rises by $47 \%$ and $112.9 \%$ for scenarios 2 and 3, respectively. The fourth scenario allowed $1000 \mathrm{ppm}$ concentration of $\mathrm{CO}_{2}$ in every room and resulted not only in the reduction of operating cost but also in the reduction of the AHU, although heat recovery efficiency was slightly lower. The operation of minimum possible cost scenario gave $22.1 \%$ of annual savings. The last scenario was a "party time" scenario assumed that additionally three persons emit $20 \mathrm{dm}^{3}$ of $\mathrm{CO}_{2}$ from 17:00 to 21:00. The result was an increase in the annual cost up to $351 €$.

Using the software one can evaluate whether the airflows and their change in time, following the designer's decision, are adequate to keep the contaminants concentration at 
a desired level. The decisions made at the designing stage can be evaluated using the software so the proper airflows can be simulated and evaluated.

The simulation results clearly show that demand controlled mechanical ventilation system (DCV) is a good solution for single family house. There is no need for complicated controls but properly programming the AHU controller can prove that it is not as expensive as rumour has it. The ventilation system can be designed for different requirements taking into consideration the user needs.

Future works will try to assess the payback time of investment in DCV ventilation system in single family dwelling.

\section{Acknowledgements}

The research has been made at Cracow University of Technology, Faculty of Environmental and Power Engineering.

The authors would like to thank for the support of the principals and staff of the Laboratory of Heating, Ventilation, Air-Conditioning and Refrigeration. We are also grateful to Kazimierz Wojtas, $\mathrm{PhD}$ from Cracow University of Technology for support and useful comments. The work has been supported by project Ś-4/296/2016/DS.

\section{References}

[1] Polska Norma (Polish Standard) PN-83/B-03430/Az3: Wentylacja w budynkach mieszkalnych zamieszkania zbiorowego i użyteczności publicznej (Ventilation in public and residential buildings). Available from: https://sklep.pkn.pl/pn-b-03430-1983-az3-2000p.html.

[2] ANSI/ASHRAE Standard 62.1-2019 Ventilation for Acceptable Indoor Air Quality 1791 Tullie Circle NE, Atlanta, GA. Available from: www.ashrae.org.

[3] Mijakowski M, Sowa J. An attempt to improve indoor environment by installing humidity-sensitive air inlets in a naturally ventilated kindergarten building, Building Environ. 2017;111:180-91. DOI: 10.1016/j.buildenv.2016.11.013.

[4] Wallner P, Munoz U, Tappler P, Wanka A, Kundi M, Shelton JF, et al. Indoor environmental quality in mechanically ventilated, energy-efficient buildings vs. conventional buildings. Int J Environ Res Public Health. 2015;12(11):14132-47. DOI: 10.3390/ijerph121114132.

[5] Nielsen TR, Drivsholm C. Energy efficient demand controlled ventilation in single family houses. Energy Buildings. 2010;42:1995-8. DOI: 10.1016/j.enbuild.2010.06.006.

[6] Evola G, Gagliano A, Marletta L, Nocera F. Controlled mechanical ventilation systems in residential buildings: Primary energy balances and financial issues. J Building Eng. 2017;11:96-107. DOI: 10.1016/j.jobe.2017.04.010.

[7] Laverge J, Van Den Bossche N, Heijmans N, Janssens A. Energy saving potential and repercussions on indoor air quality of demand controlled residential ventilation strategies. Build Environ. 2011;46:1497-503. DOI: 10.1016/j.buildenv.2011.01.023.

[8] Shin MS, Rhee KY, Lee ET, Jung GJ. Performance evaluation of $\mathrm{CO}_{2}$-based ventilation control to reduce $\mathrm{CO}_{2}$ concentration and condensation risk in residential buildings. Building Environ. 2018;142:451-63. DOI: 10.1016/j.buildenv.2018.06.042.

[9] Woradechjumroen D, Tongshoob T. Investigations of stack ventilation operations using an energy modelling and the bas system. IOP Conf. Series: Materials Sci Eng. 2020 . DOI: 10.1088/1757-899X/886/1/012040.

[10] Widiastuti R, Hasan MI, Bramiana CN, Pramesti PU. CFD simulation on the natural ventilation and building thermal performance. IOP Conf Series: Earth Environ Sci. 2020 . DOI: 10.1088/1755-1315/448/1/0120041.

[11] Jiang C, Soh YC, Masooda MK, Li H. Indoor occupancy estimation from carbon dioxide concentration. Energy Buildings. 2016;131:132-41. DOI: 10.1016/j.enbuild.2016.09.002.

[12] Ioannou A, Itard L. In-situ and real time measurements of thermal comfort and its determinants in thirty residential dwellings in the Netherlands. Energy Buildings. 2017; 139:487-505. DOI: 10.1016/j.enbuild.2017.01.050. 
[13] Zender-Świercz E. Analysis of the impact of the parameters of outside air on the condition of indoor air. Int J Environ Sci Technol. 2017;14:1-8. DOI: 10.1007/s13762-017-1275-5.

[14] Cichowicz R, Wielgosiński G. Effect of meteorological conditions and building location on $\mathrm{CO}_{2}$ concentration in the university campus. Ecol Chem Eng S. 2015;22(4):513-25. DOI: 10.1515/eces-2015-0030.

[15] Cichowicz R, Wielgosiński G, Targaszewska A. Analysis of $\mathrm{CO}_{2}$ concentration distribution inside and outside small boiler plants. Ecol Chem Eng S. 2016;23(1):49-60. DOI: 10.1515/eces-2016-0003.

[16] Cichowicz R, Wielgosiński G. Effect of urban traffic on the immision of carbon dioxide in the university campus. Ecol Chem Eng S. 2015;22(2):189-200. DOI: 10.1515/eces-2015-0010.

[17] Gładyszewska-Fiedoruk K, Ruiz de Adana M. Improving the effectiveness of stack ventilation by supplying an outdoor air stream. OP Conf Series: Materials Sci Eng. 2020; DOI: $10.1088 / 1757-899 X / 809 / 1 / 012008$.

[18] Lei1 J, Chen H, Song R. Study on design strategies about single-sided natural ventilation in residential buildings. IOP Conf. Series: Earth Environ Sci. 2020; DOI: 10.1088/1755-1315/527/1/0120141.

[19] WMO Greenhouse Gas Bulletin (GHG Bulletin) - No. 13: The State of Greenhouse Gases in the Atmosphere Based on Global Observations through 2016; 2017. Available from: https://library.wmo.int/doc_num.php?explnum_id=4022.

[20] Müller J, Skrzyniowska D. Indoor Air Quality Problems in Passive Buildings. Proc $23^{\text {rd }}$ IIR Int Congress Refrigeration: Prague, Czech Republic. August 21-26, 2011. Available from: https://iifiir.org/en/fridoc/28202.

[21] EN 15251. Indoor environmental input parameters for design and assessment of energy performance of buildings addressing indoor air quality, thermal environment, lighting and acoustics. Available from: https://sklep.pkn.pl/pn-en-15251-2012p.html.

[22] Emmerich SJ. Validation of multizone IAQ modeling of residential-scale buildings: a review. ASHRAE Trans Cincinnati. 2001 ASHRAE; 619-28. Available from: https://www.researchgate.net/publication/ 279555937_Validation_of_multizone_IAQ_modeling_of_residential-scale_buildings_A_review.

[23] Verijkazemi K, Mansouri N, Moattar F, Khezri M. Evaluation of indoor PM distribution by CONTAM airflow model and real time measuring: Model description and validation. Avicenna J Environ Health Eng. 2018;5:42-9. DOI: 10.15171/ajehe.2018.06.

[24] Barbosa BPP, Brum NDCL. Validation and assessment of the CFD-0 module of CONTAM software for airborne contaminant transport simulation in laboratory and hospital applications. Building Environ. 2018;142:139-52. DOI: 10.1016/j.buildenv.2018.06.013.

[25] Heibati S, Maref W, Saber H. Building energy and IAQ improvement by coupled model. IOP Conf Ser Mater Sci Eng. 2019; DOI: 10.1088/1757-899X/609/4/042102.

[26] Emmerich SJ. Validation of CONTAMW predictions for tracer gas in a townhouse. IBPSA, editor. 8th Int IBPSA Conf Eindhoven: IBPSA. 2003:299-306. Available from: http://www.ibpsa.org/proceedings/ BS2003/BS03_0299_306.pdf.

[27] Delsante A, Aggerholm S. The use of simulation tools to evaluate hybrid ventilation control strategies. Annex 35. Technical Report. IEA/ECBCS; 2002. Available from: https://www.ieaebc.org/Data/publications/ EBC_Annex_35_tsr.pdf.

[28] Bossche Van den N, Janssens A, Heijmans N, Wouters P. Performance evaluation of humidity controlled ventilation strategies in residential buildings. In: Thermal Performance of the Exterior Envelopes of Whole Buildings X. 2007; ASHRAE, Clearwater Beach, FL, USA, p. 7. Available from: https://web.ornl.gov/sci/buildings/conf-archive/2007\%20B10\%20papers/195_Bossche.pdf.

[29] Seong NC. Energy requirements of a multi-sensor based demand control ventilation system in residential buildings. 31st AIVC Conf Low Energy and Sustainable Ventilation Technologies for Green Buildings. 2010. Available from: https://www.aivc.org/sites/default/files/7B-2.pdf.

[30] ASHRAE Fundamentals, American Society of Heating, Refrigerating and Air-conditioning Engineers, Inc. Tullie Circle, N.E., Atlanta, GA: 2009. Available from: http://www.ashrae.org.

[31] Fanger PO. Introduction of the olf and the decipol units to quantify air pollution perceived by humans indoors and outdoors. Energy Buildings. 1988;12(1):1-6. DOI: 10.1016/0378-7788(88)90051-5.

[32] Fanger PO, Lauridsen J, Bluyssen P, Clausen G. Air pollution sources in offices and assembly halls, quantified by the olf unit. Energy Buildings. 1988;12(1):7-19. DOI: 10.1016/0378-7788(88)90052-7.

[33] Zender-Świercz E. Improving the indoor air quality using the individual air supply system. Int J Environ Sci Technol. 2018;15:689-96. DOI: 10.1007/s13762-017-1432-x.

[34] Ben-David T, Waring MS. Impact of natural versus mechanical ventilation on simulated indoor air quality and energy consumption in offices in fourteen U.S. cities. Building Environ. 2017;104:320-36. DOI: 10.1016/j.buildenv.2016.05.007. 